\title{
What do our future teachers think about terrorism and politically motivated violence in the Basque Country?
}

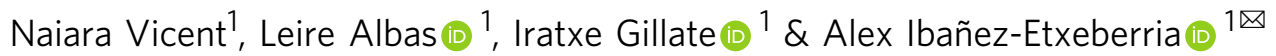

Euskadi Ta Askatasuna-Basque Country and Freedom (ETA) was an armed organisation from the Basque Country and after it declared that it would cease violent actions and subsequently disbanded, the Basque Country has been involved in a peace process. The Adiadian programme that is part of this process has been implemented as a part of teacher training programmes. By means of a mixed model that combines both qualitative and quantitative elements, the present study has attempted to identify the attitudes of future teachers-prior to implementation of Adi-adian-regarding terrorism and politically motivated violence that occurred in and from the Basque country since 1960, the information they have received with respect thereto, and their opinions as to how the issues are dealt with in the classroom. The results obtained reveal a generally respectful attitude toward human rights and the delegitimisation of violence; lack of satisfaction regarding the information they have received throughout their lives; and, as future teachers, a lack of certainty as to how to approach such issues in the classroom. It was noted that these future teachers had a high degree of motivation and interest with respect to these matters.

\footnotetext{
${ }^{1}$ University of the Basque Country (UPV/EHU), Basque country, Donostia, Spain. ${ }^{\varpi_{e}}$ email: alex.ibanez@ehu.eus
} 


\section{Introduction}

here have been a great many armed conflicts that have occurred, and that still are occurring, throughout the world. Moreover, attempts have been made to use education as a means to channel said conflicts (Cajani et al., 2019; Quaynor, 2012; Vicent et al., 2020).

During much of the second half of the 20th century and the beginning of the present century, there has been a great deal of political tension in the Basque Country. The most dramatic expression of this tension were the murders and the violation of human rights perpetrated by terrorist groups, as well as by means of violent actions carried out by the State and its security forces (Carmena et al., 2013). Basque society has experienced an anomalous situation marked by terrorism, kidnappings, torture, threats, extortion, exile and, in general, a lack of freedom. The suffering, fear, emotions, and high tensions characteristic of those times have given rise to numerous conflicts among the territory's citizens. However, after ETA declared an end to violence and subsequently disbanded, the Basque Country entered into a new stage of gradually returning to normality. During this stage, Basque society has been faced with the challenge of learning anew how to coexist on the basis of respect for the memory of victims of past violence.

Public institutions, as well as other diverse entities, have been promoting policies regarding this issue, and the Basque government's own responsibility for addressing such matters is undeniable. Within the realm of public policy, we have seen initiatives on the part of the Secretary of Peace, Coexistence, and Human Rights of the Basque government, which consists of a series of plans (Gobierno Vasco, 2007, 2010, 2013, 2017). These plans have addressed the way Basque terrorism and political violence are dealt with in educational settings. We can therefore confirm that, from the time of the first educational proposals put forward by the Coordinadora Gesto por la Paz (1997), a course has been embarked on that has at times been controversial (Urkidi et al., 2021), and which culminated in the consolidation of The Adiadian educational module: Teaching about human dignity, coexistence, and empathy through victim testimony (Gobierno Vasco, s.f.), the main programme of this type currently being implemented in the Basque Country. The purpose of the present research project is to analyse various aspects of this programme's implementation from the standpoint of teaching in the social sciences, and specifically in the context teacher training in the Basque Country's public university.

\section{Citizenship education and controversial issues in post- conflict societies}

Within the context of nation-states, the teaching of history traditionally sought to educate citizens in order to promote national unity on the basis of a common identity (Carretero et al., 2012; Smith, 1991). The method of choice for this purpose has been a closed and linear narrative (Carretero et al., 2004). However, modern citizenship education places an emphasis on human rights, democracy, the rule of law, respect for diversity, and the culture of political participation (Sen, 2019). As pointed out by Deveci et al. (2008), civic education and knowledge of the social sciences allow people to address social issues (i.e., war, peace, democracy, citizenship, human rights) with a view toward implementing peace education.

However, Rubin and Cervinkova (2019) believe that global efforts to address democratic coexistence within an educational context have failed to address both complex issues of the past and sources of discrepancy within communities. These authors recognise the difficulty of confronting "difficult histories", while at the same time emphasising the opportunity that these selfsame histories offer for better understanding the present, and for constructing a fairer and more inclusive version of democracy. In this regard, Cuesta (2011) points out the importance of what is actually remembered, and the purpose that we assign to memory. Within a specifically educational context, he champions the duty to remember specific moments and situations of the past in order to prevent their recurrence.

In the specific case of post-conflict societies, Corredor et al. (2018) contend that education for peace must include the study of authoritarian regimes and violent conflicts, as well as the suffering of victims. Padilla and Bermúdez (2016) believe that these issues have not received sufficient attention in programmes of study. These latter authors are also of the opinion that the "questioning of violence, irrespective of its perpetrators and victims, constitutes an ethical imperative for engendering a critical understanding of said violence that could serve as the foundation of a sustainable culture of peace" (p. 245).

In the opinion of Arnoso et al. (2018), it is violent events that are best preserved within collective memory. However, these authors also emphasise the importance of forgetting and silence on the part of those persons who still suffer when they relive those violent events. In addition, these authors criticise the attempts of certain groups to silence or distort the past in order to neutralise or minimise actions, and to attribute responsibility to "the other". In this regard, Arnoso et al. (2018) also point to the teaching of history as being responsible for making certain conflicts invisible, and they offer a series of recommendations to avoid such an outcome. These recommendations include reflecting on what is historically meaningful and why it is meaningful; questioning the motives for stressing certain historical elements in preference to others; avoiding the normalisation of the central role of violence and conflict as a form of progress; and promoting positive collective emotions, stressing the role of survivors and their descendants. They further add that, in those cases in which certain memories have been silenced in books, other resources need to be employed, such as personal testimonies.

Rubin and Cervinkova (2019) contend that democratic citizenship education has become part and parcel of the reconstruction of post-conflict societies in such disparate settings as Bosnia and Herzegovina, Colombia, Guatemala, Northern Ireland, Rwanda, Lebanon, Indonesia, Laos, Argentina, Peru, Cyprus, and South Africa (Quaynor, 2012). Yet they also point out that, in countries like Guatemala and Poland, the opportunity afforded by reconstruction has not been exploited in such a way as to involve young persons in the critical reading of history, and in a way that provides space for alternative voices.

For these reasons, it seems that there is room for improvement in both civic education and the teaching of the social sciences within educational institutions. Thus, in spite of good intentions on the part of teachers (Delgado-Algarra, 2014), the result is that they are left with a number of unresolved problems that arise from political differences. These unresolved problems can prevent institutional proposals for education from either being consolidated, as in Spain (Gómez-Rodríguez and García-Ruiz, 2019), or from achieving their objectives, as in Northern Ireland (O'Connor et al., 2020). Other problems in this regard are the violence occurring within schools located in conflict zones (Kuppens and Langer, 2018), and the contradiction between the attempt to offer citizenship education and the inherent authoritarian nature of the school and its professors (Díaz-Perdomo and Rojas-Suárez, 2019; Quaynor, 2012), which ignores the rights of students (Waldron and Oberman, 2016). Yet another complication is a fear on the part of faculty of conflicts arising in the classroom (Quaynor, 2012; Toledo et al., 2015), which in turn leads to an avoidance of political discussion, the preference being to offer authoritarian instruction via unquestionable and biased 
comments of the past (Skaras and Breidlid, 2016). Similarly, it is emotionally difficult-and sometimes even painful-for some teachers to delve into socially controversial issues (Vidal de Almeida, 2019; Zembylas et al., 2011). Finally, it is also possible that attempts to narrate the different aspects of conflict could lead to an inaccurate understanding of current realities, a phenomenon that has, according to Tegeer (2015) occurred in South Africa.

Another rather difficult task has to do with overcoming the biased versions of events that students can find in places outside of the school (Barton and McCully, 2005), especially in the family, which tends to be the primary source of information within conflict zones (Vidal de Almeida, 2019), but also from friends or mass media (Reidy et al., 2015). It is also no easy matter-as has been shown in Chile (Reyes et al., 2016) - to challenge the perception of inaccessibility that young persons may have as regards historical memory, resulting from not being able to find spaces within which to take a position, challenge, or express solidarity vis-à-vis past conflicts.

For all these reasons, and taking full account of the complexity of the matter, it seems important to offer proper and comprehensive training to teachers in societies that are currently experiencing, or that have recently experienced, internal conflicts (Kuppens and Langer, 2018). With a view to constructing spaces of coexistence, Silva-Peña and Paz-Maldonado (2019) see a place for the inclusion of emotional education. We have also witnessed demands on the part of new teachers and teachers-in-training for the inclusion of peace education (Deveci et al., 2008) or intercultural education (Mason, 2005) within teacher training programmes. Finally, Quaynor (2012) defends the need for institutional support through the creation of teacher-training programmes and specific curriculum materials. The more comprehensive the support received by teachers during their training, the easier it will be for schools to offer their students what they require: the ability to deal with current topics of a controversial nature (Montanares, 2017; Vidal de Almeida, 2019) and the possibility for them to exercise their own rights (Quaynor, 2012).

As regards the attitude of young persons vis-à-vis known conflicts, it has been observed at the international level that Liberian students show a concern for justice (Quaynor, 2015), while in Chile and Northern Ireland, empathy and solidarity in the face of the suffering of the other have been in evidence (Reyes et al., 2016; Vidal de Almeida, 2019). In this connection, it is worth noting that the implementation of a series of programmes in countries like Colombia (Chaux et al., 2017) and Peru (Espinosa et al., 2019) have succeeded in reducing violent and authoritarian behaviour among students. In addition, in South Africa (Finkel and Ernst, 2005), Liberia (Quaynor, 2015) and Bosnia-Herzegovina (Soule, 2000), the incorporation of citizenship education led to higher levels of respect for human rights and for peace, as well as to enhanced capacity for democratic action. In addition, participants in these kinds of initiatives not only have more information at their disposal (Espinosa et al., 2019; Montanares, 2017), but also displayed increased levels of interest (Quaynor, 2012) or improved their political education (Finkel and Ernst, 2005; Soule, 2000). Furthermore, in the case of future teachers, there was an acquisition of skills that would enable the transfer of these kinds of initiatives for addressing conflict into the classroom (Montanares, 2017).

\section{Public policy and educational approach to terrorism and politically motivated violence in the Basque Country}

In the specific case of the Basque Country, recent memory includes ongoing human rights violations right up to the initial years of the 21 st century. These acts of violence have resulted in a large number of victims (Carmena et al., 2013; Landa, 2008).
Although these events have occurred over the course of many years, some research identifies a lack of knowledge among young Basques (Usón, 2017) and Spaniards (Felices de la et al., 2019). It was not until 2004 that a diagnosis of the educational approach to this issue in classrooms was undertaken. The 2004 study showed that the educational community identified the Basque conflict with suffering and social division. Also noted at that time was silence on the part of a large segment of the educational community - a silence that was interpreted as a desire to keep political opinions out of the educational setting out of fear of potentially harmful consequences. Given the significant emotional component of the conflict, teachers did not feel either competent or comfortable with the subject, which became a source of frustration, disgust, and powerlessness. Even though teachers as a collective condemned acts of violence, they also expressed their fear that the way this violence was dealt with in the classroom could constitute an obstacle to peaceful coexistence. Students and families, on the other hand, did show an interest in dealing with the subject of these acts of violence in the classroom. And yet some teachers felt that demands could not be made to deal with the subject in classrooms until such time as an educational proposal enjoying broad consensus had been put in place. At the same time, these very teachers were demanding that educational administrators provide orientation, resources, and consultation in order to deal with the subject (Gobierno Vasco, 2004).

In the wake of these findings, the First Basque Plan for Peace Education and Human Rights (2008-2011) (Gobierno Vasco, 2007) incorporated teaching materials that were challenged in some quarters (Urkidi et al., 2021). However, an evaluation of the usefulness of the plan in terms of social-emotional development and promotion of historical memory yielded positive results (Garaigordobil, 2009). In addition, the Garaigordobil study provided a series of recommendations regarding the future application of the Plan: maintaining and reinforcing activities involving victims of violence; initiating debates regarding current topics relevant to the lives of young persons, and promoting the exchange of positive messages; inclusion of activities encouraging the peaceful and cooperative resolution of conflicts; implementation of programmes at all educational levels; and contextualising intervention beyond the classroom-in schools, in families, and in society in general.

Later on, and following publication of the proposal Stories that impact our lives (Arana et al., 2006), which had already included the comments of victims, a greater degree of consensus emerged as regards the educational usefulness of testimonies (Urkidi et al., 2021). Thus, in 2011, the programme Victims who educate was launched, by means of which the first stories of victims came to be heard and discussed in classrooms. It was on the basis of that experience that the proposal on which the present paper focuses emerged-namely The Adi-adian educational module: Teaching about human dignity, coexistence, and empathy through victim testimony (Gobierno Vasco, s.f.). This programme involved listening in person to the reflections of victims who, following their experiences, called for coexistence rather than hatred, and through which the subjects of human dignity, human rights, and co-existence were addressed.

It was within this framework that more comprehensive proposals such as Bakeaz Blai were presented. An evaluation of Bakeaz Blai (Ruiz and Salazar, 2014) concluded that the following factors were conducive to the proper implementation of the programme: involvement and education of families and teachers; the previous experience of the school as regards education for peace and coexistence; and the teaching of skills on the part of teachers implementing the programme. In addition, the 2014 study identified the involvement of victims as a key element of the proposal. Ruiz and Salazar (2014) also contended that it 
was possible to implement Bakeaz Blai without incorporating the distinct political viewpoints of victims on both sides of the conflict, "since, irrespective of where the victimisation originated, the function of the victim who educates is to share their experience, and the injustice that they suffered" (p. 546), with the comprehensive vision of human rights being the central focus of the programme itself.

\section{Studies of Basque youth, terrorism, and politically motivated violence}

One of the first indices of the attitudes of Basque youth regarding the subject under discussion was offered by a study on the transmission of values to minors (Elzo et al., 2009), and which included a section dedicated to the analysis of the attitudes of students toward ETA and terrorism. This study found that the majority of the young persons studied offered support to victims of terrorism, although this response was not unanimous. In fact, there was also evidence of evaluations and attitudes that reflected lack of respect for basic human rights, with part of the sample not rejecting-or even justifying-acts of violence and terrorism. Some respondents, on the other hand, did not recognise the human rights of ETA members. On the basis of the responses obtained, Elzo identified three groups of persons: one that justified the actions of ETA and showed sensitivity regarding the human rights of its members; a second that defended in general terms the human rights of every person, rejecting ETA's violence, but at the same time recognising their human rights; and a third that categorically rejected ETA's violence, and that placed special emphasis on the human rights of victims of terrorism, but without recognising the human rights of ETA members. Elzo et al. (2009) also found-as Barton and McCully (2005) subsequently did in a later study within the context of Ireland-that the family was a first-order agent that explained the different positions of students regarding the subject.

Some 8 years later, Usón (2017), in an analysis of 939 questionnaires distributed to students aged 18 through 29 enroled in social science and education programmes in three different Basque universities, found that youth embraced a discourse of defence of and respect for human rights. Even so, he found that a significant minority of subjects (12\%) were not entirely opposed to ETA's violent actions. In addition, the students in the study indicated that they were highly interested in knowing what had happened, while expressing their dissatisfaction with the information they had thus far received. Students' level of knowledge regarding what had happened was found to be very limited. Participants identified mass media as their main source of information, followed by family, social networks, friends, and books. Students also indicated that their families exercised far more influence on their knowledge of the subject than did their schools. Finally, participants indicated that they experienced a lack of freedom to publicly express their views regarding the subject (Usón, 2017).

In addition, Portraits of youth, an ongoing series of studies that began in 1997 under the auspices of the Department of Sociological Research of the Basque Government in order to identify the views of youth aged 15 through 29 regarding various subjects, offers a number of clues. In the latest published study of this series (2018) it was noted that violence and terrorism did not appear among the problems most frequently cited by respondents, as had been the case in 2001, when it was identified as the main problem. However, coexistence in the Basque Country among persons with differing ideologies received a score of 6.5 on a scale of 0 to 10 , with 0 representing a very bad situation and 10 a very good situation. For their part, youth expressed moderate satisfaction with compliance with human rights (67\%) and democracy $(58 \%)$ in the Basque Country. Finally, the study indicated that $70 \%$ of youth had little or no interest in politics.

A recent study of political education of youth (Larrinaga et al., 2020), confirms the finding of Elzo et al. (2009) in identifying the family as the main source of influence on youth and the construction of their ideologies. In the case of politically active youth, political affiliation and memory transmitted within the home both exercised an important influence. On the other hand, young persons who are less politically involved had heard nothing about politics from their families. School was a source of lesser influence, although the study did reveal that secondary education constituted a period of initiation of discussion or political activity, outside of the family environment, and among friends. As regards university, some of the respondents in the study of Larrinaga et al. (2020) defined it as a space of knowledge of new political settings. Finally, a certain measure of fear could be discerned in the reported experiences of respondents: fear of either state repression or of ETA. Reference to such fear was more common among participants aged 25 and older, given that those in this age group had direct memories of episodes of violence.

\section{Context and objectives of study}

The Adi-adian proposal, which primarily focused on students in secondary education (aged 12-18) was first implemented in the initial training of future teachers enroled in the Department of Education, Philosophy, and Anthropology of the University of the Basque Country (UPV-EHU) in the year 2016 as part of a project entitled Coexistence and memory. In addition to providing information regarding the socio-political context of the Basque Country during recent decades, and to providing students an opportunity to hear victim testimony, the aim of this project was to provide a set of professional skills to facilitate the teaching of social sciences through the presentation of controversial subjects (Santisteban, 2019), citizenship education (Banks, 2017), peace education (Etxeberria, 2013) and education in and for conflict (Cascón, 2001).

Barton (2015) emphasises the importance of knowing the baseline prior to carrying out teaching procedures, given that student attitudes toward human rights depend on the context of their lives and experience. Following Barton, and given that the ultimate goal of this study is to optimise the adaptation of the Adi-adian programme within the context of training future teachers, the objectives of this paper are as follows:

1. To analyse attitudes previously held by teachers-in-training in the Basque Country as regards terrorism and political violence that occurred in and from the Basque Country since 1960

2. To identify the views of students in their role as teachers with regard to treatment of controversial issues in the classroom.

3. To identify the sources and quality of information received by students regarding terrorism and politically motivated violence that occurred in and from the Basque Country since 1960 .

\section{Methodology}

Design. Díaz López (2014) has expressed the view that research, construed as the possibility of understanding, interpreting, and transforming reality, cannot be divorced from the ongoing demands of a world that is increasingly unstable, complex, and diverse. It is for this reason that, in the eyes of many researchers and theorists, the two traditional research paradigms do not go far enough in resolving problems and situations that require fresh perspectives and innovative, in-depth approaches. It is within this 
context that mixed research methods have emerged as a third alternative. Mixed designs represent the highest level of integration or combination of qualitative and quantitative approaches (Hernández et al., 2003) and allow researchers to take advantage of the strengths of both in order to attain a more comprehensive understanding of social phenomena generally and educational phenomena more specifically.

This paper takes as its point of departure a mixed methodological approach, in the understanding that it offers complementariness as well as different kinds of knowledge and advantages for those conducting research (Boeije, 2010) in the quest for a more complete view of reality through a multifaceted analysis of a single aspect of that reality (Santiago et al., 2018).

The research comprises two descriptive studies, independent of one another in the final sample. Study 1 is of a quantitative nature, and based on questionnaire responses, while Study 2 is qualitative, and focuses on the interpretation of the narratives of informants.

Participants. A total of 204 students who were training to become future teachers participated in Study 1. The participants were drawn from three different teacher programmes at the University of the Basque Country (UPV-EHU): Degrees in Preschool Education $(n=45)$ and Primary Education $(n=138)$; and a Master's Degree in Secondary Education Teacher Training in social sciences $(n=21)$.

For Study 2, we collected narratives from 112 students enroled in teacher-training programmes at the Primary Education level $(n=85)$, and in a Master's programme for teaching the social sciences in secondary education $(n=27)$ at the same university.

Measurement tools. This research study employed two measurement instruments. For Study 1, a self-administered questionnaire (see Appendix) consisting of 29 items was used, having taken into consideration previous work published by the Instituto de Derechos Humanos Pedro Arrupe (2017) y Garaigordobil (2009). In this questionnaire, 28 of the items request that respondees select responses in accordance with a four-point Likert scale. The first item of the questionnaire provides multiple response options. The researchers sought to identify student attitudes as regards factors, such as empathy, violation of human rights, addressing conflicts, managing emotions, commitment to maintaining peace, recognition of and reparations for victims, and the treatment of controversial issues in formal education settings. The researchers also wanted to identify sources of the respondents' information, as well as their level of satisfaction with respect to the information that they had received regarding terrorism and politically motivated violence occurring in, and perpetrated from the Basque Country since the year 1960.

A preliminary version of the questionnaire was utilised in a pilot trial conducted in November 2019. The results of this trial were submitted to experts for the purposes of validation, with needed adjustments made to the questionnaire based on said validation, thus creating the final version of the instrument.

The instrument utilised for Study 2 was the narrative obtained on the basis of the thinking routine "I used to think...now I think..." Specifically, Study 2 took into account the information relative to "I used to think...", with responses classified in accordance with nine nodes or subjects (Table 1).

Procedure. After obtaining prior approval from the University of the Basque Country's Ethics Committee for Research Involving Human Beings (M10/2019/197), the questionnaire was administered under routine teaching conditions prior to implementation of the Adi-adian programme. The narratives were composed

\begin{tabular}{|l}
$\begin{array}{l}\text { Table } 1 \text { Classification of nodes referring to student } \\
\text { narratives. }\end{array}$ \\
$\begin{array}{ll}\text { 1. Quantity of information } \\
\text { received }\end{array}$ \\
$\begin{array}{ll}\text { 1.1. A lot } & \text { 4. Human rights } \\
\text { 1.2 A little } & \text { 4.1 Respect for human rights } \\
\text { 1.3. None } & \text { 4.2 Violation of human rights } \\
& \text { 5. Attitude toward addressing } \\
\text { 2. Sources of information } & \text { conflicts } \\
\text { 2.1. School environment } & \text { 5.1 Positive } \\
\text { 2.2. Friends } & \text { 5.2 Negative } \\
\text { 2.3. Written documents } & \text { 6. Commitment to peace process } \\
\text { 2.4. Visual media } & \text { 6.1. Yes } \\
\text { 2.5. Family } & \text { 6.2. No } \\
\text { 2.6. Mass media } & \text { 7. Motivation regarding the subject } \\
\text { 2.7. Social networks } & \text { 7.1. Yes } \\
\text { 3. Expressions of empathy } & \text { 7.2. No } \\
& \text { 8. Treatment of subject in the } \\
\text { 3.1 Yes } & \text { classroom } \\
\text { 3.2 No } & \text { 8.1. Favourable }\end{array}$
\end{tabular}

following the conclusion of this programme, and took into account only information relative to the part "I used to think..." Both the questionnaire and the narratives were collected anonymously or pseudonymously, with each questionnaire assigned a code. The language employed in the questionnaires was either Spanish or Basque. In addition, at the conclusion of the teaching project, signed informed consent forms were obtained from participants for the purpose of later publication of data.

Data analysis. For Study 1, after it was initially established that there were neither anomalous data nor non-random missing data, descriptive statistics and frequency tables were calculated for each of the items on the questionnaire. Data were statistically analysed using the programme IBM SPSS Statistics 25.

For Study 2, a thematic analysis of the narratives was conducted utilising the programme NVivo12. Responses were classified in nodes or subjects, and frequencies were obtained for each of the nodes.

The datasets generated during the current study are not publicly available because they are part of a larger project under study, but are available from the corresponding author on reasonable request.

\section{Results}

The first objective of the investigation was to identify the prior attitudes of teachers-in-training regarding terrorism and politically motivated violence in and from the Basque Country. Responses to items related to empathy (Table 2) indicate that, even though a minority of the respondents (5.9\%) indicated that reparations to victims of violence was of little or no importance, the vast majority (92.6\%) expressed total or general agreement with statements regarding recognition of the suffering of victims (item 8), about the importance of being attentive to the suffering of others (94.1\%; item 23), and regarding putting oneself in another person's shoes (98.2\%; item 24 ).

The narratives include 12 references to the subject of empathy, with 10 of the narratives expressing an empathetic attitude. Thus, the respondent to questionnaire P511 indicated that everything experienced by these persons has been unfair; each one of them has suffered in their own way, and they should not be rejected for having different thoughts. On the other hand, P642 wrote that, when it came to talking about this subject, they saw the suffering in the face of other persons, and for this reason never wanted to ask 
Table 2 Degree of empathy.

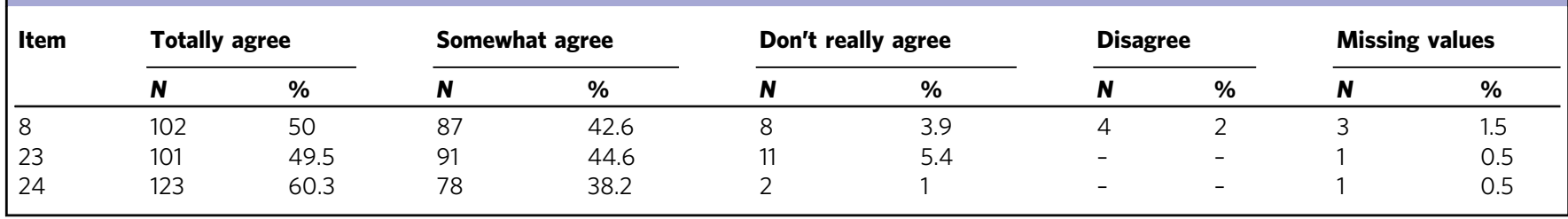

Table 3 Human rights.

\begin{tabular}{|c|c|c|c|c|c|c|c|c|c|c|}
\hline Item & \multicolumn{2}{|c|}{ Totally agree } & \multicolumn{2}{|c|}{ Somewhat agree } & \multicolumn{2}{|c|}{ Don't really agree } & \multicolumn{2}{|c|}{ Disagree } & \multicolumn{2}{|c|}{ Missing values } \\
\hline 3 & 123 & 60.3 & 64 & 31.4 & 13 & 6.4 & 1 & 0.5 & 3 & 1.5 \\
\hline 7 & 83 & 40.7 & 89 & 43.6 & 26 & 12.7 & 2 & 1 & 4 & 2 \\
\hline 9 & 100 & 49 & 64 & 31.4 & 25 & 12.3 & 5 & 2.5 & 10 & 4.9 \\
\hline 10 & 46 & 22.5 & 96 & 47.1 & 38 & 18.6 & 8 & 3.9 & 16 & 7.8 \\
\hline 15 & 78 & 38.2 & 106 & 52 & 17 & 8.3 & 1 & 0.5 & 2 & 1 \\
\hline 16 & 125 & 61.3 & 59 & 28.9 & 2 & 1 & - & - & 18 & 8.8 \\
\hline 17 & 56 & 27.5 & 89 & 43.6 & 32 & 15.7 & 5 & 2.5 & 22 & 10.8 \\
\hline
\end{tabular}

a lot of questions about it, so as not to reawaken those memories and feelings. However, another respondent (P484) indicated that inevitably, because of their convictions and position regarding the subject, they were not able to have a great deal of empathy for persons who held opposing views.

Turning to the responses related to human rights (Table 3 ), the results of Study 1 indicate that a large majorities of the respondents either totally agreed or somewhat agreed (91.7\%) with the notion that a person's right to life is more important than any political project (item 3); rejected violence that constitutes an attack on human dignity (item 4), while considering the consequences of violence to be negative (item 7). However, differences emerged with respect to the origin of the violence. Thus, while $49 \%$ of students were unequivocally against ETA violence (item 9), only $22.5 \%$ of students selected the same option in instances in which it was the state that violated basic rights in the name of the fight against terrorism (item 10).

On the other hand, responses to items 3, 4, 9, and 10 indicate that a minority of respondents do justify violence. Item 3 states that the right to life of a person is more important than any political project. Some $9.9 \%$ of the student respondents indicated they did not really agree, or that they disagreed, with this assertion, and $1.5 \%$ of data were missing. Similarly, responses to item 4 , which asserts that violent actions against human dignity should be rejected, $6.9 \%$ of responses indicated dissent, with $3.4 \%$ of data missing. Responses to item 9, declaring opposition to ETA violence, revealed that $14.8 \%$ were in disagreement, with $4.9 \%$ of data unreported. Finally, as regards the affirmation that the state violates basic human rights in its fight against terrorism, $22.5 \%$ of respondents either did not really agree, or actually disagreed, and $7.8 \%$ of the data were missing.

Further results regarding the issue of human rights indicate that the respondents are aware of the need to live on the basis of positive values (item 14 ), given that $80.19 \%$ totally agree with this assertion, while $61.3 \%$ indicated that they were aware of the presence of persons in the Basque Country with diverse beliefs and values (item 16). In contrast, only $38.2 \%$ expressed total agreement with the assertion of being a tolerant person who accepts and understands the ideas and choices of others, while not necessarily being in agreement with them (item 15). And only $27.5 \%$ indicated total agreement with the need to construct a common culture that includes all of those persons (item 17).

As regards the narratives, there are only eight references to the issue of human rights. One of these references mentions respect, while the other seven refer to violation of human rights, the most frequent references being to the number of murders, kidnappings, abuse, or instances of torture-or to lack of recognition of victims. Thus, respondent $\mathrm{P} 405$ indicated I did not think that there were so many murders, abuses, kidnappings, instances of torture... by groups who were fighting against the groups that fought for the independence of the Basque Country (e.g. ETA). P439 wrote I thought that they killed people who were involved, that all of the victims were recognised, and that ETA had not killed so many people. As regards the violation of human rights by the State in the name of fighting terrorism, one narrative mentions the policy of dispersion instituted by the Spanish government: We are now paying for the consequences for what happened before. There are political prisoners who continue to be dispersed in different prisons. In addition, the younger generations continue to suffer oppression today...the Basque Country continues to be under attack because of its past (P645).

Another item relevant to human rights has to do with the extent to which peace prevails in the Basque Country, and the freedom to express one's opinions there. In this connection, respondent P425 wrote the following: In this society, there is theoretically freedom of opinion and ideas. But a number of experiences that I have had in this programme have confirmed my previous fear: that if your opinion is different from that of the majority of the class, they won't respect it. In contrast, another respondent (P643) suggests that listening in different ways to ideas and opinions based on different ideologies enabled him to have enough freedom and maturity to form his own ideas.

As regards the addressing of conflicts (Tables 4), 10.8\% of the student respondents expressed total agreement with the notion that sometimes persons have no choice but to use violence (item 5). On the other hand, $96 \%$ either totally agreed or somewhat 
Table 4 Addressing conflicts.

\begin{tabular}{|c|c|c|c|c|c|c|c|c|c|c|}
\hline \multirow[t]{2}{*}{ Item } & \multicolumn{2}{|c|}{ Totally agree } & \multicolumn{2}{|c|}{ Somewhat agree } & \multicolumn{2}{|c|}{ Don't really agree } & \multicolumn{2}{|c|}{ Disagree } & \multicolumn{2}{|c|}{ Missing values } \\
\hline & $\mathbf{N}$ & $\%$ & $\boldsymbol{N}$ & $\%$ & $\mathbf{N}$ & $\%$ & $\boldsymbol{N}$ & $\%$ & $\boldsymbol{N}$ & $\%$ \\
\hline 5 & 22 & 10.8 & 64 & 31.4 & 84 & 41.2 & 33 & 16.2 & 1 & 0.5 \\
\hline 6 & 138 & 67.6 & 58 & 28.4 & 5 & 2.5 & - & - & 3 & 1.5 \\
\hline 19 & 67 & 32.8 & 122 & 59.8 & 13 & 6.4 & - & - & 2 & 1 \\
\hline 21 & 72 & 35.3 & 108 & 52.9 & 7 & 3.4 & - & - & 17 & 8.3 \\
\hline 22 & 56 & 35.2 & 81 & 50.9 & 5 & 3.1 & - & - & 17 & 8.3 \\
\hline \multirow[t]{2}{*}{ Item } & \multicolumn{2}{|c|}{ Very high } & \multicolumn{2}{|l|}{ High } & \multicolumn{2}{|c|}{ Low } & \multicolumn{2}{|c|}{ Very low } & \multicolumn{2}{|c|}{ Missing values } \\
\hline & $\mathbf{N}$ & $\%$ & $\mathbf{N}$ & $\%$ & $\boldsymbol{N}$ & $\%$ & $\boldsymbol{N}$ & $\%$ & $\mathbf{N}$ & $\%$ \\
\hline 20 & 49 & 24 & 133 & 65.2 & 20 & 9.8 & - & - & 2 & 1 \\
\hline
\end{tabular}

Table 5 Managing emotions.

\begin{tabular}{|c|c|c|c|c|c|c|c|c|c|c|}
\hline Item & \multicolumn{2}{|c|}{ Totally agree } & \multicolumn{2}{|c|}{ Somewhat agree } & \multicolumn{2}{|c|}{ Don't really agree } & \multicolumn{2}{|c|}{ Disagree } & \multicolumn{2}{|c|}{ Unreported } \\
\hline 25 & 73 & 35.8 & 120 & 58.8 & 9 & 4.4 & 1 & 0.5 & 1 & 0.5 \\
\hline
\end{tabular}

Table 6 Commitment of respondents to the pacification process.

\begin{tabular}{|c|c|c|c|c|c|c|c|c|c|c|c|c|}
\hline Item & \multicolumn{3}{|c|}{ Totally agree } & \multicolumn{2}{|c|}{ Somewhat agree } & \multicolumn{2}{|c|}{ Don't really agree } & \multicolumn{2}{|c|}{ Disagree } & \multicolumn{3}{|c|}{ Missing values } \\
\hline 11 & 25 & 12.3 & & 114 & 55.9 & 50 & 24.5 & 11 & 5.4 & 4 & & 2 \\
\hline \multirow[t]{2}{*}{ Item } & \multicolumn{3}{|c|}{ Very high } & \multicolumn{2}{|c|}{ High } & \multicolumn{2}{|c|}{ Low } & \multicolumn{2}{|c|}{ Very low } & \multicolumn{3}{|c|}{ Missing values } \\
\hline & $\mathbf{N}$ & $\%$ & & $N$ & $\%$ & $N$ & $\%$ & $N$ & $\%$ & $\mathbf{N}$ & & $\%$ \\
\hline 28 & 64 & 31.4 & & 108 & 52.9 & 23 & 11.3 & 1 & 0.5 & 8 & & 3.9 \\
\hline 29 & 41 & 20.1 & & 127 & 62.3 & 28 & 13.7 & 2 & 1 & 6 & & 2.9 \\
\hline
\end{tabular}

agreed that there are better ways than violence to resolve problems (item 6). For items 21 and 22, which respectively, refer to the realisation one attains regarding where they stand regarding a conflict and the attempt to analyse how to constructively confront a problem, $8.3 \%$ of data were unreported.

As regards the narratives, although there are expressions of not knowing how to deal with such a sensitive subject, 13 out of the 15 narratives express a positive attitude vis-a-vis addressing conflicts. Respondent P546 expressed their fear of not knowing how to manage conflict situations, although it is an important subject to work on. $\mathrm{P} 412$ wrote that, as future primary education teachers, it will be of fundamental importance to know how to deal with conflicts. Another student (P19) indicated that violence constitutes legitimate political action, although it is necessary to have the support of large segments of society in order to be able to repair the damage done.

The results summarised in Table 5 indicate that students were capable of distinguishing negative feelings from positive feelings (item 26), and of reflecting on the source of negative feelings (item 25).

The results of Study 2 offer only two references to the management of emotions. Respondent P454 mentioned the fear of not knowing how to manage a conflict situation, while P463 wrote that before beginning the project, I was afraid of talking about the
Basque conflict, since we generally deal with it in a subjective way, considering one ideology as right and the other as wrong. For that reason, I was afraid of dealing with the subject: because of what others would think, wondering if they would think the same way as I do.

Table 6 displays the results of those items related to the peace process. As regards item 11, only $12.3 \%$ of student respondents indicated that there is currently a climate of peace in the Basque Country, while $29.9 \%$ either do not really agree, or frankly disagree with this assertion. Similarly, only $15.7 \%$ of students totally agreed that they feel free to express in public what they think about terrorism and the violation of human rights in the Basque Country (item 27). Also worthy of note is the fact that $82.4 \%$ of participants would be committed to participating in actions that promote peace and coexistence (item 29), while $84.3 \%$ accord a high degree of importance to the acceptance of and reparations to victims of human rights violations in the Basque Country (item 28).

The narratives reflect a great deal of interest and motivation on the part of students vis-à-vis the subject (Table 7). P837 wrote: $I$ have always been interested in Basque history and culture, the conflicts that occurred in the Basque Country, and how the society in which we live reflects the importance of all this. It is important to sometimes have programmes of this kind (P803). P825 indicated that it is anteresting subject, and I think that it is indispensable 
for being able to understand the situation that we are living in today, while P640 asserted that it seems very important to me to be aware of what has happened in our land. Finally, P3 wrote: I think that it is something positive to work on the history of the recent past (especially on the subject of conflict) in class, and to use primary sources in doing so.

As for the results with respect to the second objective-the treatment of the subject in schools (Table 8)-one can readily see the difference in the responses offered to the three different items. While $85 \%$ of students completely agreed with the idea of encouraging people to have positive social values such as solidarity, equality, etc. (item 13 ), only $59.3 \%$ totally agreed with the notion of conducting activities for the purpose of looking for alternatives to violent behaviour (item 12). In addition, fewer than $50 \%$ of the respondents ascribed positive value to the idea of it being possible to speak in schools of the socio-political reality in order to engender a commitment to active engagement (item 18). It is also noteworthy that $10.3 \%$ of respondents were not in agreement with the assertion of item 18 , and that $3.4 \%$ of the data related to this item were unreported.

Respondents who mentioned it in their narratives (Table 9) felt that working on this subject with children could be difficult and hard; that it wasn't worth mentioning in order to avoid conflict (P480); that it is a dangerous subject to bring up; and that it is better not to mention it and to let each have their own beliefs (P422). According to respondent P25, it is a deep and complex subject, and it isn't easy to decide which methodology would be best for bringing this kind of subject into the classroom. On the other hand, others thought that it is important to work on the subject with primary school students (P447), because it is a historical event that occurred in the place where we were born, and therefore it is a subject that should be addressed in all of the schools of the Basque Autonomous Community (P837) or because we have a lack of information (P629).

The third objective of this paper concerns the quality, nature, and sources of information received by students regarding terrorism and politically motivated violence in and from the Basque Country beginning in the year 1960. The results of Study 1 (Table 10) show that the primary source of information was the family, followed by mass media and then the school (item 1).

In contrast, the sources mentioned most frequently in the narratives in Study 2 (Table 11) are the school setting (i.e., primary school and secondary school), family (i.e., parents and

\section{Table 7 Narratives: No. of references to commitment and motivation regarding the subject.}

\begin{tabular}{|ll|} 
Nodes & References \\
\hline 7. Commitment to peace process & 27 \\
7.1. Yes & 18 \\
7.2. No & 9 \\
8. Motivation regarding the subject & 21 \\
8.1. Yes & 16 \\
8.2. No & 5 \\
\hline
\end{tabular}

grandparents) and visual media (i.e., documentaries and/or movies). Respondent P13 mentioned that, as regards the Basque conflict, I have always been curious about why, how, and even where things happened. To find out, I would often ask at home, and I have tried to have discussions with acquaintances, and to look up information on the internet.

In response to the question as to the degree of satisfaction with the information that had been received (item 2) of Study 1, the majority of students expressed dissatisfaction (Table 12).

Among the narratives for Study 2, there were 51 respondents who mentioned having known something about the subject prior to participation in the Adi-adian programme. One respondent indicated that, prior to participating in the programme, I had little information about the "Basque Conflict" and its victims, although I did have rudimentary knowledge of the subject (P801). The narratives offered reflect students' lack of satisfaction with the information that they had previously received. Thus, respondent P629 felt that the year that they worked the most on the subject was in the history course during the second year of baccalaureate, but not in the way that they would have liked, because there was some information that was not provided. P447 expressed similar sentiments, writing that, after having dealt with this subject in class in a number of papers, exercises, and surveys, it has to be said that they had a lot of disinformation. One participant (P18) indicated that they did not know about the subject, and that most of the information they received during the project was new.

\section{Discussion}

The results pertaining to politically motivated violation of human rights occurring in and perpetrated from the Basque Country within recent memory, are very similar to those obtained in other studies (Elzo et al., 2009; Gobierno Vasco, 2004; Usón, 2017). In general terms, the future teachers who were the subjects in this study were clearly in favour of respecting human rights, and of rejecting violence. In addition, subjects generally displayed empathy and sensitivity to the suffering of victims, and were in favour of providing reparations to those victims. Furthermore, the respondents in this study were inclined to take an active role in the maintenance of peace. However, as Elzo et al. (2009) reported, it is possible to catch a glimpse of a small minority of participants who seem to justify violence, and who have difficulties in understanding "the other". Such is the case of persons who do not place life above a political project, who do not unequivocally reject violence against persons or the violence perpetrated by ETA, and who do not recognise either the need to construct an inclusive culture, or to provide reparations to victims. It is rather more complicated to interpret the responses of those persons who acknowledge not always having been able to avoid violence. These responses are probably justified owing to the complexity involved in managing conflicts, and to the many different degrees of violence, given that there was nearly unanimous agreement among respondents that violence is not the best way to resolve problems. On the other hand, less than one quarter of participants clearly and categorically acknowledge violence on the part of the State. Even though the State itself has acknowledged perpetrating

Table 8 Treatment of subject in school.

\begin{tabular}{|c|c|c|c|c|c|c|c|c|c|c|}
\hline \multirow[t]{2}{*}{ Item } & \multicolumn{2}{|c|}{ Totally agree } & \multicolumn{2}{|c|}{ Somewhat agree } & \multicolumn{2}{|c|}{ Don't really agree } & \multicolumn{2}{|c|}{ Disagree } & \multicolumn{2}{|c|}{ Missing values } \\
\hline & $\mathbf{N}$ & $\%$ & $\mathbf{N}$ & $\%$ & $\mathbf{N}$ & $\%$ & $\mathbf{N}$ & $\%$ & $\mathbf{N}$ & $\%$ \\
\hline 12 & 121 & 59.3 & 55 & 27 & 5 & 2.5 & 2 & 1 & 21 & 10.3 \\
\hline 13 & 174 & 85.3 & 27 & 13.2 & 2 & 1 & - & - & 1 & 0.5 \\
\hline 18 & 89 & 43.6 & 87 & 42.6 & 17 & 8.3 & 4 & 2 & 7 & 3.4 \\
\hline
\end{tabular}




\begin{tabular}{|ll|}
\hline $\begin{array}{l}\text { Table } 9 \text { Narratives: Treatment of the subject in the } \\
\text { classroom. }\end{array}$ & References \\
\hline Nodes & 18 \\
\hline 9. Treatment of the subject in the classroom & 8 \\
9.1 In favour & 10 \\
9.2 Have reservations &
\end{tabular}

\begin{tabular}{|c|c|c|}
\hline \multirow[t]{2}{*}{ Item } & \multicolumn{2}{|c|}{ References } \\
\hline & $\mathbf{N}$ & $\%$ \\
\hline School & 83 & 52.2 \\
\hline Family & 106 & 66.7 \\
\hline Friends & 47 & 29.6 \\
\hline Mass media & 97 & 61 \\
\hline Social networks & 70 & 44 \\
\hline Books & 20 & 12.6 \\
\hline Other & 7 & 4.4 \\
\hline
\end{tabular}

\begin{tabular}{|ll|}
\hline $\begin{array}{l}\text { Table } \mathbf{1 1} \text { Respondents' narratives: Number of references for } \\
\text { different sources of information. }\end{array}$ \\
Nodes & References \\
\hline 2. Sources of information & 45 \\
2.1. School setting & 30 \\
2.2. Friends & 6 \\
2.3. Written documents & 3 \\
2.4. Visual media & 10 \\
2.5. Family & 26 \\
2.6. Mass media & 6 \\
2.7. Social networks & 3 \\
\hline
\end{tabular}

\begin{tabular}{|c|c|c|c|c|c|c|c|c|c|c|}
\hline \multirow[t]{2}{*}{ Item } & \multicolumn{2}{|c|}{$\begin{array}{l}\text { Very } \\
\text { satisfied }\end{array}$} & \multicolumn{2}{|c|}{$\begin{array}{l}\text { Fairly } \\
\text { satisfied }\end{array}$} & \multicolumn{2}{|c|}{$\begin{array}{l}\text { Not very } \\
\text { satisfied }\end{array}$} & \multicolumn{2}{|c|}{$\begin{array}{l}\text { Very } \\
\text { unsatisfied }\end{array}$} & \multicolumn{2}{|c|}{ Missing values } \\
\hline & $\mathbf{N}$ & $\%$ & $\mathbf{N}$ & $\%$ & $\mathbf{N}$ & $\%$ & $\mathbf{N}$ & $\%$ & $\mathbf{N}$ & $\%$ \\
\hline 2 & 2 & 1 & 33 & 16.2 & 105 & 51.5 & 59 & 28.9 & 5 & 2,5 \\
\hline
\end{tabular}

violence, this only occurred a few years ago (Landa, 2008; Carmena et al., 2013). For this reason, the results obtained may be a consequence of the transmission of an officially sanctioned memory that has silenced part of the history (Arnoso et al., 2018).

In order to assure a future that is more inclusive and open to coexistence, the objective should be to put an end to the following tendencies noted in the results of the present study: the justification of violence (Elzo et al., 2009); the fear associated with these issues (Larrinaga et al., 2020), and the perception that there is room for improvement when it comes to coexistence (Gabinete de prospección sociológica-Gobierno Vasco, 2018). But, in addition to providing citizenship education, we should not forget that we are also training teachers and that, given the difficulties that teachers have in incorporating and dealing with issues of conflict in the classroom (Gobierno Vasco, 2004; Quaynor, 2012; Skaras and Breidlid, 2016; Toledo et al., 2015; selfcite; Vidal de Almeida, 2019;
Zembylas et al., 2011), it is absolutely essential to provide our future teachers the tools that they need in order to properly deal with these kinds of situations, as Quaynor (2012) argues.

As we have discovered, there are those who believe that there is not really peace within the Basque Country in which we live. There are also those who do not believe that they can express themselves freely. In addition, in spite of a majority who feel otherwise, there are persons who have reservations about approaching these issues in the classroom. What all this shows is the difficulty in bringing an end to a conflict that has become deeply rooted over the course of many years. For this reason, it is all the more necessary, however complicated it may be to confront these difficult events (Rubin and Cervinkova, 2019) and to overcome the fears of teachers about fomenting discord in the classroom (Quaynor, 2012; Toledo et al., 2015; Vidal de Almeida, 2019; Zembylas et al., 2011), that we see the presentation in the classroom of the history of violence and terrorism in the Basque Country as an opportunity, especially as it relates to the teacher training. A proper understanding of what occurred-one that eschews any kind of distorted equivalence in the damage caused (Tegger, 2015) - could lead to a change in attitude among the population. Over and apart from an ethical commitment to education aimed at remembering what happened in order to prevent it from being repeated (Cuesta, 2011), and of offering youth the information that they do not know (Felices de la et al., 2019; Usón, 2017) and are demanding (Espinosa et al., 2019; Montanares, 2017), the objective should be to educate teachers who promote the kind of citizenship education (Sen, 2019) that safeguards the fundamental rights of all persons in the face of any conflict that might arise. As regards this issue, today's students who will become the teachers of tomorrow recognise the importance the work that takes place in schools-work that strives to identify alternatives to violence, and that seeks to foment the acquisition of positive values, as recommended by Garaigordobil (2009). The benefits of which have also been set forth in a number of different international studies (Finkel and Ernst, 2005; Soule, 2000; Quaynor, 2015).

Thus, with a view to optimising the usefulness of the present study, we think it fitting to follow the guidelines set forth by Arnoso et al. (2018), who contend that history should be dealt with in a way that is conscious, reflective, and critical, but without drifting into biased viewpoints. It also seems appropriate to encourage, in opposition to the central role so long held by violence, the development of positive emotions, as recommended by Garaigordobil (2009). This last factor is interesting in terms of the work on emotional education that is advocated by Silva-Peña and Paz-Maldonado (2019). On the other hand, Garaigordobil (2009) also thought it important that these kinds of programmes be accompanied by activities that encourage conflict resolution, and this is something that is even more interesting to us in the case of educating future teachers. In addition, both Garaigordobil (2009) and Ruiz and Salazar (2014) emphasised the important role of the school and the family, which in our view should be taken into account in the design of any programming that incorporates the Adi-adian module. All of this should be implemented in a way that promotes peaceful and inclusive environments that facilitate the dispelling of fears over speaking about the subject, and that provides space for the experiencing and expression of emotions.

As regards sources of information, the majority of students expressed clear dissatisfaction with the information that they had received-a finding consistent with previous studies (Usón, 2017). What this finding shows is that subjects such as those addressed in this study that deal with social conflict are not often dealt with in certain sectors of society. As has been established in previous studies conducted in the Basque Country (Elzo et al., 2009; Larrinaga et al., 2020) and in contexts outside of Spain 
(Vidal de Almeida, 2019), it has been conclusively shown that the family is an important source of information, as are schools and mass media (Reidy et al., 2015; Usón, 2017).

On the other hand, friends are not often referred to as a source of information, which leads to the conclusion that the subject is not something that is spoken of among peers (Larrinaga et al., 2020). This may be because it is a subject that seems remote to young people. However, this finding flies in the face of the motivation that youth claim to have as regards learning about the subject, as shown in the present study as well as in other studies of the Basque Country (Gobierno Vasco, 2004; Usón, 2017) and in other former conflict zones such as Northern Ireland (Vidal de Almeida, 2019). This leads us to conclude that the reason that the subject is not spoken of might be the lack of social space to do so, as described by Reyes et al. (2016) with reference to Chile; the fear of expressing one's opinion (Larrinaga et al., 2020; Usón, 2017); or the fear of dealing with situations that are emotionally complicated (Rubin and Cervinkova, 2019).

\section{Conclusions and future lines of research}

Future teachers of the Basque County generally have a respectful attitude regarding human rights and delegitimising violence. However, there is some concern over the possible existence of a small minority that justifies the violence experienced during recent decades. It is for this reason that future lines of research should aim at an in-depth identification of student attitudes regarding violence. To this end, qualitative studies should be conducted that are aimed at expanding upon the data gathered in the present study. On the other hand, it is our view that the official history may have provided a biased reading of the violence that was experienced, although we do not have data at our disposal that would support such a conclusion. This is why we need to know what our students know regarding the recent violent history of the Basque Country. Because of both of the foregoing problems, it is necessary to evaluate the efficacy of the programme Adi-adian, and of similar programmes in order to find out if they provide an improved critical understanding of the past, of respect for human rights, and of the delegitimising of violence. On the other hand, the treatment of controversial issues such as the one dealt with in this paper must constitute a priority in teacher training, for one very important reason: to dispel the fears expressed over raising those kinds of subjects-and especially over raising them in classrooms in their role as teachers. Accomplishing this goal will also promote the kind of citizenship education that includes not only peace education, but also emotional and intercultural education.

At the same time, it also seems important to us to emphasise the dissatisfaction expressed by students regarding the information they had previously received about the subject, as well as the motivation and interest of these self-same students regarding the subject. It is for this reason that we have the obligation to give back to students-within formal educational settings and elsewhere-the right to know which is rightfully theirs. Furthermore, given the importance that the family has been shown to have in the transmission of knowledge regarding the subject, it would seem fitting to also incorporate the family in any future educational proposals.

Furthermore, considering that this topic has also been discussed with young people outside the Basque Country, it might be interesting to extend future research to other areas of Spain.

Finally, confirmation should be sought of the notion that mixed methods of educational research allow researchers to make progress in particular with regard to complex research topics such as the one addressed in this paper. Such an approach, because of its multifaceted nature in terms of ethics and politics, is conducive to a vision that is both more diverse and more conducive to fostering empathy.

\section{Data availability}

The datasets generated during the current study are not publicly available because they are part of a larger project under study, but are available from the corresponding author on reasonable request.

Received: 30 September 2020; Accepted: 14 January 2021; Published online: 05 February 2021

\section{References}

Arana R, Harillo S, Prieto J (2006) Historias que nos marcan: las víctimas del terrorismo en la educación para la paz: guía didáctica para Educación Secundaria. Bakeaz, Bilbao

Arnoso M, Páez D, Bobowik M, Basabe N (2018) Implicaciones de los estudios sobre memoria colectiva para la enseñanza de la historia. Arbor 194(788): a445. https://doi.org/10.3989/arbor.2018.788n2005

Banks JA (2017) Failed citizenship and transformative civic education. Educ Res 46 (7):366-377. https://doi.org/10.3102/0013189X17726741

Barton KC (2015) Young adolescents' positioning of human rights: findings from Colombia, Northern Ireland, Republic of Ireland and the United States. Res Comp Int Educ 10(1):48-70. https://doi.org/10.1177/1745499914567819

Barton KC, McCully AW (2005) History, identity, and the school curriculum in northern ireland: an empirical study of secondary students' ideas and perspectives. J Curric Stud 37(1):85-116. https://doi.org/10.1080/ 0022027032000266070

Boeije H (2010) Analysis in qualitative research. SAGE Publications Ltd, London

Cajani, L., Lässig, S. \& Repoussi, M. (2019). The Palgrave handbook of conflict and history education in the post-cold war era. Palgrave Macmillan, Cham.

Carmena M, Landa JM, Múgica R, Uriarte JM (2013) Informe-base de vulneraciones de derechos humanos en el caso vasco (1960-2013). Secretaria de Paz y Convivencia (Gobierno Vasco), Vitoria-Gasteiz

Carretero M, Asensio M, Rodríguez-Moneo M (eds) (2012) History education and the construction of national identities. Information Age Publishing.

Carretero M, Jacott L, López Manjón A (2004). La enseñanza de la historia a través de los libros de texto. In: Carretero En M, Voss JF (eds). ¿Se les enseña la misma historia a los alumnos mexicanos que a lo españoles? Amorrortu, Buenos Aires, pp. 153-173.

Cascón Soriano P (2001). Educar en y para el conflicto. UNESCO.

Chaux E, Barrera M, Molano A, Velásquez AM, Castellanos M, Chaparro MP, Bustamante A (2017) Classrooms in peace within violent contexts: field evaluation of Aulas en Paz in Colombia. Prev Sci 18(7):828-838. https://doi. org/10.1007/s11121-017-0754-8

Coordinadora Gesto por la Paz (1997) Educarnos en la tolerancia-Tolerantzian geure burua hezitzea (12-18 años). Coordinadora Gesto por la Paz, Bilbao

Corredor J, Wills-Obregon ME, Asensio-Brouard M (2018) Historical memory education for peace and justice: definition of a field. J Peace Educ 15 (2):169-190. https://doi.org/10.1080/17400201.2018.1463208

Cuesta R (2011) Historia con memoria y didáctica crítica. Concienc Soc 15:15-30

Delgado-Algarra EJ (2014). Educación para la ciudadanía en la enseñanza de las ciencias sociales y su vinculación con las dimensiones de la memoria: estudio de caso en ESO. Tesis doctoral, Universidad de Huelva.

Deveci H, Yilmaz F, Karadag R (2008) Pre-service teachers' perceptions of peace education. Eurasian J Educ Res 8(30):63-80

Díaz López SM (2014) Los métodos mixtos de investigación: presupuestos generales y aportes a la evaluación educativa. Rev port pedagogía 48(1):7-23. https://doi.org/10.14195/1647-8614_48-1_1

Díaz-Perdomo ML, Rojas-Suarez ND (2019) Educación para la ciudadanía en el posacuerdo. Eleuthera 20:13-34. https://doi.org/10.17151/eleu.2019.20.2

Elzo J, Barrutia A, Ibáñez M, Laespada T, Leonardo J (2009) La transmisión de valores a menores. Ararteko, Vitoria-Gasteiz

Espinosa A, Cueto RM, Páez D (2019). Reflecting upon the years of political violence in Peru: an experimental study to promote a culture of peace in higher education. J Prev Interv Community. https://doi.org/10.1080/10852352.2019.1664710

Etxeberria X (2013) La educación para la paz reconfigurada. La perspectiva de las víctimas. Catarata, Madrid

Felices de la F, María del M, Chaparro Sainz Á (2019) Concepciones del profesorado en formación sobre temas controvertidos: ETA como contenido histórico. In: Hortas MJ, Dias A, de Alba N (Eds.) Enseñar y aprender didáctica de las ciencias sociales: La formación del profesorado desde una perspectiva sociocrítica. AUPDCS, Instituto Politécnico de Lisboa, ESEL, Lisboa, pp. 477-483

Finkel S, Ernst HR (2005) Civic education and the development of political knowledge and democratic orientations in post-apartheid South Africa. Political Psychol 26 (3):333-364. https://doi.org/10.1111/j.1467-9221.2005.00421.x

Gabinete de Prospección Sociológica-Gobierno Vasco (2018). Retratos de juventud 2017. https://www.euskadi.eus/retratos-de-juventud/web01-s1lehike/es/ 
Garaigordobil M (2009) Evaluación del programa "Dando pasos hacia la pazBarerako urratsak": informe de investigación. Gobierno Vasco, Vitoria-Gasteiz

Gobierno Vasco (2004) Educación para la convivencia y la paz en los centros escolares de la CAPV. Gobierno Vasco, Vitoria-Gasteiz

Gobierno Vasco (2007) Plan Vasco de Educación para la Paz y los Derechos Humanos (2008-2011). Gobierno Vasco, Vitoria-Gasteiz

Gobierno Vasco (2010) Convivencia democrática y deslegitimación de la violencia (2010-2011). Reformulación del Plan Vasco de Educación para la Paz y los Derechos Humanos (2008-2011). Gobierno Vasco, Vitoria-Gasteiz

Gobierno Vasco (2013) Plan de Paz y Convivencia 2013-16. Un objetivo de encuentro social. Gobierno Vasco, Vitoria-Gasteiz

Gobierno Vasco (2017) Un objetivo de encuentro social, la opción por la empatía. Gobierno Vasco, Vitoria-Gasteiz

Gobierno Vasco (s.f.). Módulo educativo Adi-Adian. Aprendizajes de dignidad humana, convivencia y empatía mediante una experiencia de escucha de testimonios de víctimas. Gobierno Vasco, Vitoria.

Gómez Rodríguez AE, García Ruiz CR (2019) Educación para la ciudadanía en españa. una asignatura para la confrontación ideológica y política. Didáct Cienc Exp Soc 37:51-66. https://doi.org/10.7203/dces.37.14318

Hernández R, Fernández C, Baptista P (2003) Metodología de la investigación. Editorial McGraw-Hill, México

Instituto de Derechos Humanos Pedro Arrupe (2017). Conocimiento y discurso de la población universitaria sobre terrorismo y vulneración de derechos humanos en Euskadi. Gobierno Vasco.

Kuppens L, Langer A (2018) Peut-on apprendre la paix à l'école? Une valuation du cours « Éducation aux droits de l'homme et à la citoyenneté " (EDHC) en Côte d'Ivoire post-conflit. Int Rev Educ 64(5):633-650. https://doi.org/ $10.1007 / \mathrm{s} 11159-018-9729-7$

Landa JM (2008) Informe sobre víctimas de vulneraciones de derechos humanos derivadas de la violencia de motivación política. Gobierno Vasco, Vitoria-Gasteiz

Larrinaga A, Zabalo J, Epelde M, Iraola I, Odriozola O, Amurrio M (2020). Parte hartu ala paso egin? Gazteen ikasketa politikoak aztergai. Parte Hartuz Ikerketa Taldea (UPV/EHU). https://www.ehu.eus/es/web/partehartuz/interesgarria

Mason T (2005) From the Balkans to the Baltics: challenges for civic education in two eastern European countries. Int J Soc Educ 20:115-131

Montanares E (2017) ¿Cuánto sabemos de la historia reciente? Iber 88:34-39

O'Connor U, Anderson Worden E, Bates J, Gstrein V (2020) Lessons learned from 10 years of citizenship education in Northern Ireland: a critical analysis of curriculum change. Curric J 31(3):479-494. https://doi.org/10.1002/curj.2

Padilla A, Bermúdez Á (2016) Normalizar el conflicto y des-normalizar la violencia: Retos y posibilidades de la enseñanza crítica de la historia del conflicto armado colombiano. Rev Colomb Educ 71:219-251

Quaynor LJ (2012) Citizenship education in post-conflict contexts: a review of the literature. Educ Citizsh Soc Justice 7(1):33-57. https://doi.org/10.1177/ 1746197911432593

Quaynor L (2015) 'I do not have the means to speak:' educating youth for citizenship in post-conflict Liberia. J Peace Educ 12(1):15-36. https://doi.org/ 10.1080/17400201.2014.931277

Reidy CM, Taylor LK, Merrilees CE, Ajduković D, Biruški DČ, Cummings EM (2015) The political socialization of youth in a post-conflict community. Int J Intercult Relat 45:11-23. https://doi.org/10.1016/j.ijintrel.2014.12.005

Reyes MJ, Cruz MA, Aguirre FJ (2016) Los lugares de memoria y las nuevas generaciones: algunos efectos políticos de la transmisión de memorias del pasado reciente de Chile. Rev Esp Cienc Política 41:93-114. https://doi.org/ $10.21308 /$ recp. 41.04

Rubin BC, Cervinkova H (2019) Questioning silences: democratic citizenship education and historical memory in Poland and Guatemala. Anthropol Educ Q 51(2):178-194. https://doi.org/10.1111/aeq.12329

Ruiz G, Salazar R (2014) Bakeaz Blai: Programa Pedagógico con Víctimas Educadoras. Oñati Socio-legal Ser 4(3):525-549. http://ssrn.com/abstract=2368140

Santiago K, Jiménez O, Lukas J (2018). Metodo mistoak Hezkuntza-ikerkuntzan. Tantak 30(1). https://doi.org/10.1387/tantak.19827

Santisteban A (2019) La enseñanza de las Ciencias Sociales a partir de problemas sociales o temas controvertidos: estado de la cuestión y resultados de una investigación. El Futuro Pasado 10:57-79. https://doi.org/10.14516/ fdp.2019.010.001.002

Sen A (2019) Changes and continuities in citizenship education: What kind of citizenship education does the 2018 social studies programme of study envisage? J Qual Res Educ 7(1):1-28. https://doi.org/10.14689/issn.21482624.1.7c1s.1m

Silva-Peña I, Paz-Maldonado E (2019). Formación docente para la justicia social desde la perspectiva emocional: Indagaciones narrativas en el contexto de la revolución del torniquete. Rev Interuniv Form Profr, 33(3). https://doi.org/ 10.47553/rifop.v33i3.75652

Skaras M, Breidlid A (2016) Teaching the violent past in secondary schools in newly independent South Sudan. Educ Change 20(3):98-118. https://doi.org/ $10.17159 / 1947-9417 / 2016 / 1312$
Smith AD (1991) National identity. Penguin Books, London

Soule S (2000). Beyond communism and war: the effect of civic education on the democratic attitudes and behavior of Bosnian and Herzegovinian youth https://www.semanticscholar.org/paper/Beyond-Communism-and-War\%3AThe-Effect-of-Civic-on-of-Soule/e6f9ec99dc2586b5043cfd3fecc95f80dc9123d6

Teeger C (2015) "Both sides of the story" history education in post-apartheid South Africa. Am Sociol Rev 80(6):1175-1200. https://doi.org/10.1177/ 0003122415613078

Toledo MI, Magendzo A, Gutiérrez V, Iglesias R, López R (2015) Enseñanza de "temas controversiales" en el curso de historia, desde la perspectiva de los estudiantes chilenos. Rev estud soc 52:119-133. https://doi.org/10.7440/ res52.2015.08

Urkidi P, Lores G, Vicent N, Delgado A (2021). Problemas sociales relevantes y módulo educativo Adi-adian: una apuesta por la educación en derechos humanos, valores democráticos y la memoria histórica reciente en Euskadi. Unpublished manuscript.

Usón Gónzalez I (2017) Terrorismo y vulneraciones de derechos humanos de motivación política en el caso vasco: Estudio exploratorio sobre los conocimientos y la valoración ética de la juventud universitaria vasca. Deusto J Hum Rights $=$ Rev Deusto Derechos Humanos 2:121-148. https://doi.org/ 10.18543/djhr-2-2017pp121-148

Vicent N, Castrillo J, Ibañez-Etxeberria A, Albas L (2020) Conflictos armados y su tratamiento en educación. análisis de la producción científica de los últimos 25 años en la web of science. Panta Rei 14(2):55-91. https://doi.org/10.6018/ pantarei.445721

Vidal de Almeida D (2019). O legado dos Passados Dolorosos: como são ensinados os The Troubles aos jovens, na Irlanda do Norte? Tesis doctoral, Universidade do Porto.

Waldron F, Oberman R (2016) Responsible citizens? How children are conceptualised as rights holders in Irish primary schools. Int J Hum Rights 20 (6):744-760. https://doi.org/10.1080/13642987.2016.1147434

Zembylas M, Charalambous P, Charalambous C (2011) Teachers' emerging stances and repertoires towards reconciliation: potential and challenges in GreekCypriot education. J Peace Educ 8(1):19-36. https://doi.org/10.1080/ 17400201.2011 .553378

\section{Acknowledgements}

This project has received financial support from the office of the Vice Rector for Innovation, Social Outreach and Cultural Activities of the University of the Basque Country (UPV-EHU) via the Educational Innovation Project Memory and coexistence (HBP201920/102); from the Basque Government, via the Research Group GIPyPAC, UPV/EHU (IT1193-19), and from the Department of Peace and Coexistence of the Basque Government and the: Vice-Rectorate for Basque Language and Continuing Education of the University of the Basque Country (UPV-EHU) (PIC INVEC3L4-D00024-1).

\section{Competing interests}

The authors declare no competing interests.

\section{Additional information}

Supplementary information The online version contains supplementary material available at https://doi.org/10.1057/s41599-021-00721-0.

Correspondence and requests for materials should be addressed to A.I.-E.

Reprints and permission information is available at http://www.nature.com/reprints

Publisher's note Springer Nature remains neutral with regard to jurisdictional claims in published maps and institutional affiliations.

Open Access This article is licensed under a Creative Commons Attribution 4.0 International License, which permits use, sharing, adaptation, distribution and reproduction in any medium or format, as long as you give appropriate credit to the original author(s) and the source, provide a link to the Creative Commons license, and indicate if changes were made. The images or other third party material in this article are included in the article's Creative Commons license, unless indicated otherwise in a credit line to the material. If material is not included in the article's Creative Commons license and your intended use is not permitted by statutory regulation or exceeds the permitted use, you will need to obtain permission directly from the copyright holder. To view a copy of this license, visit http://creativecommons.org/ licenses/by/4.0/

(C) The Author(s) 2021 